\title{
Titanium Dioxide Nanoparticles and Sodium Nitroprusside Alleviate the Adverse Effects of Cadmium Stress on Germination and Seedling Growth of Wheat (Triticum aestivum $\mathrm{L}$. )
}

\author{
Javad Faraji ${ }^{1}$, Ali Sepehri ${ }^{1, *}$
}

\begin{abstract}
Edited by
Juan Carlos Salcedo-Reyes

(salcedo.juan@javeriana.edu.co)

1. Department of Agronomy and Plant Breeding, Faculty of Agriculture, Bu-Ali Sina University, Hamedan, Iran.

*sepehri110@yahoo.com

Received: 06-28-2017

Accepted: 01-30-2018

Published on line: 03-03-2018

Citation: Faraji J, Sepehri A. Titanium Dioxide Nanoparticles and Sodium Nitroprusside Alleviate the Adverse Effects of Cadmium Stress on Germination and Seedling Growth of Wheat (Triticum aestivum L.),

Universitas Scientiarum, 23 (1): 61-87, 2018. doi: 10.11144/Javeriana.SC23-1.tdna
\end{abstract}

Funding: N.A.

Electronic supplementary material: N.A.

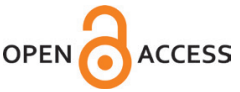

\begin{abstract}
Effect of titanium dioxide nanoparticles $\left(\mathrm{TiO}_{2} \mathrm{NPs}\right)(0,500,1000$ and $2000 \mathrm{mg} / \mathrm{L}$ ) and sodium nitroprusside (SNP) (0 and $100 \mu \mathrm{M})$ as nitric oxide (NO) donor, on wheat seed germination and seedling growth were investigated under cadmium $(\mathrm{Cd})$ stress $(0,50$ and $100 \mathrm{mM} \mathrm{CdCl}$ ). Concentration-dependent declining trends were observed in wheat germination indices upon seed exposure to $\mathrm{CdCl}_{2}$ suspensions which were more obvious under higher $\mathrm{Cd}$ stress. Exogenous sodium nitroprusside (SNP) and $\mathrm{TiO}_{2}$ nanoparticles (NPs) positively affected most germination indices under normal and stress conditions. In most cases, combined application of $\mathrm{TiO}_{2}$ NPs and SNP suspensions boosted stimulatory function of both compounds and moderated adverse effects of $\mathrm{Cd}$ treatments on wheat seed germination and seedling growth. $2000 \mathrm{mg} / \mathrm{L} \mathrm{TiO}_{2}+\mathrm{SNP}(100 \mu \mathrm{M})$ treatment recorded the best results regarding most germination indices under lower and higher (50 and $100 \mathrm{mM} \mathrm{C \textrm {Cl } _ { 2 }}$ ) Cd stress. Overall, it could be concluded that application of $\mathrm{TiO}_{2}$ NPs in combination with SNP might be a promising approach in counteracting the adverse effects of $\mathrm{Cd}$ stress on wheat seed germination and early growth.
\end{abstract}

Keywords: Cadmium stress; Germination; Nitric oxide; $\mathrm{TiO}_{2}$ nanoparticles; Wheat

\section{Introduction}

Engineered nanomaterials (ENMs) have many unique properties such as their small size, large surface area, chemical composition, surface reactivity, charge, shape, and media interactions. These physical, chemical, thermal, magnetic, optical, and biological properties have resulted in numerous applications including use in food and common everyday products [1]. Titanium is the ninth most abundant element and the second most abundant transition metal 
in the earth's crust [2]. Anatase, rutile, and brookite are common forms of $\mathrm{TiO}_{2}$ [3]. Titanium dioxide NPs are among the ten most commonly produced ENMs that are used worldwide [4] with global production of this particle now standing at 10000 tons per year [5]. Commercial production of $\mathrm{TiO}_{2}$ NPs has been estimated to reach approximately 2.5 million tons by 2025 [6]. Titanium dioxide NPs are commonly used in a broad range of products such as paints, papers, inks, coatings, catalysts, solar cells, plastics, soaps, antimicrobial and antifungal agents, alloys, textiles, food products, toothpaste, sunscreen and cosmetics, medicines and pharmaceuticals [7], in certain sectors of agriculture [8], and in environmental cleanup technologies [9]. Recently, $\mathrm{TiO}_{2} \mathrm{NPs}$ have been reported to improve seed germination and plant growth [10-12]. For example, simultaneous application of $\mathrm{SiO}_{2}$ and $\mathrm{TiO}_{2}$ nanoparticles accelerated germination and growth of soybean (Glycine max) plants by improving water uptake and increasing the activity of nitrate reductase and antioxidant system [13]. Positive effect of $\mathrm{TiO}_{2}$ nanoparticles on spinach germination is likely related to the small particle size which enables $\mathrm{TiO}_{2}$ NPs to penetrate into the seed and promote germination and growth [10].

Abiotic stresses such as drought, salinity, heavy metals, and temperature affect germination, growth, and some physiological processes in plants [14]. Cadmium (Cd) is considered to be one of the most phytotoxic heavy metals which can be released into the environment via different agricultural or industrial activities. Soil pollution by $\mathrm{Cd}$ in many agricultural fields is mainly attributed to the prolonged application of phosphate fertilizers or field irrigation through sewage sludge or waste water $[15,16]$. Nitric oxide (NO) is known as a gaseous signaling molecule that participated in some critical physiological process within the plants such as seed germination, cell death or expansion, stomata closure and root growth [17 - 20]. Nitric oxide plays a key role in seed germination of different species under stress condition [21, 22]. Nitric oxide is well known to play a dual role in the stress responses of plants. In particular, NO can directly scavenge certain reactive oxygen species (ROS), such as superoxide anions and lipid-derived radicals, and was proven to induce antioxidant enzymes thereby decreasing oxidative damage $[17,23]$. In recent years, there is abundant evidence to support the protective role of exogenous NO released by a NO donor; such as SNP in alleviating heavy metals-induced phytotoxicity. For example, pretreatment with SNP ameliorated toxic effects of $\mathrm{Cd}$ on wheat $[24,25]$ barley [26] and rice [27] by boosting the antioxidant defense system.

Seed germination and root/shoot elongation tests are considered as sensitive, fast and effective methods to assess the phytotoxicity of nanoparticles 
in plants [28]. Different test media such as culture solution [29], agar medium [30], filter paper on petri dish [31] and soil [32] have used in literature to evaluate the impact of nanoparticles on seed germination and early growth of various plant species. Filter paper on petri dish method which used in current survey appeared to be simple and widely-used method in nanoparticle phytotoxicity experiments [33]. Wheat (Triticum aestivum) was selected as plant material for the current study as recommended for the testing of chemicals by USEPA [34] and OECD [35].

Although both stimulatory and inhibitory impacts of nanoparticles on various crop species have been reported in the literature, however information regarding nanoparticles function under heavy metal stress is still limited. To the best of our knowledge, this study is the first report on the protective role of $\mathrm{TiO}_{2}$ NPs and SNP in ameliorating the adverse effects of $\mathrm{Cd}$ on seed germination and seedling growth of wheat. The data obtained in this survey can pave the way for further investigations in this field and shed lights on new applications of nanoparticles, in particular, $\mathrm{TiO}_{2}$ nanoparticles accompanied by stress-ameliorating compounds such as SNP in alleviating Cd stress in plants and improving plant growth under unfavorable condition.

\section{Materials and methods}

\section{Plant material}

Wheat (var. Pishgam) seeds were supplied by the Seed and Plant Improvement Institute (SPII), Karaj, Iran. Seeds were stored in a dry place at room temperature before use. The average germination rates of the tested seeds were greater than $90 \%$, according to our preliminary study.

\section{Nanoparticle Characterization}

Titanium dioxide NPs were procured from Iranian Nanomaterials Pioneers Company (NANOSANY), Mashhad, Iran. According to the data provided by the manufacturer, $\mathrm{TiO}_{2}$ NPs used in this study had the following features: primary size: $10-25 \mathrm{~nm}$, surface area: $200-240 \mathrm{~m}_{2} \cdot \mathrm{g}^{-1}, \mathrm{pH}: 6-6.5$, bulk density: $0.24 \mathrm{~g} . \mathrm{cm}^{-3}$, true density: $3.9 \mathrm{~g} . \mathrm{cm}^{-3}$, and $99 \%$ purity. A transmission electron microscopy (TEM) image of the $\mathrm{TiO}_{2}$ particles is shown (Fig. 1). The crystal properties of $\mathrm{TiO}_{2} \mathrm{NPs}$ were examined by X-ray diffraction (XRD). The XRD measurement showed that used $\mathrm{TiO}_{2} \mathrm{NPs}$ were all present in the anatase form (Fig. 2). 


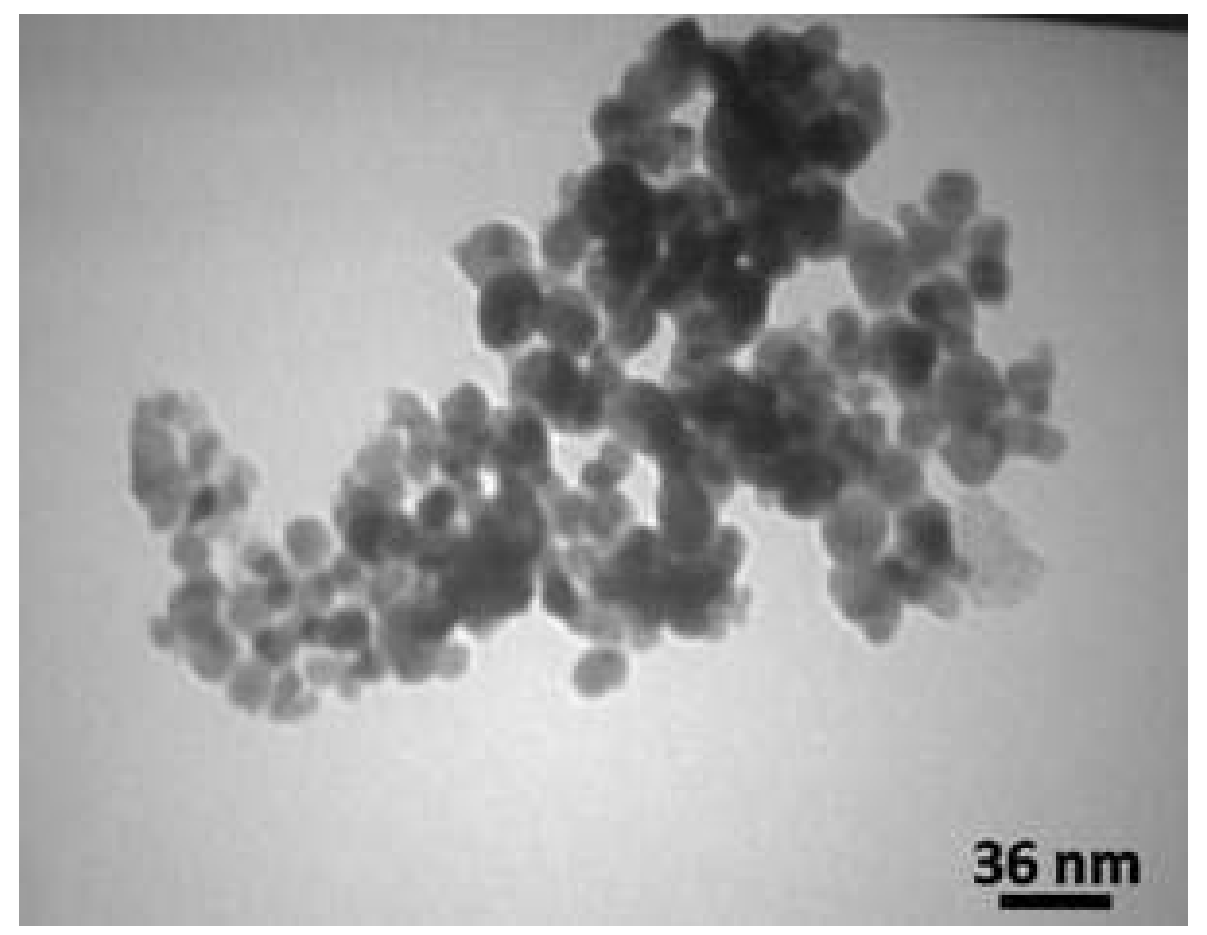

Figure 1. Transmission electron microscopy (TEM) image of $\mathrm{TiO}_{2}$ nanoparticles .

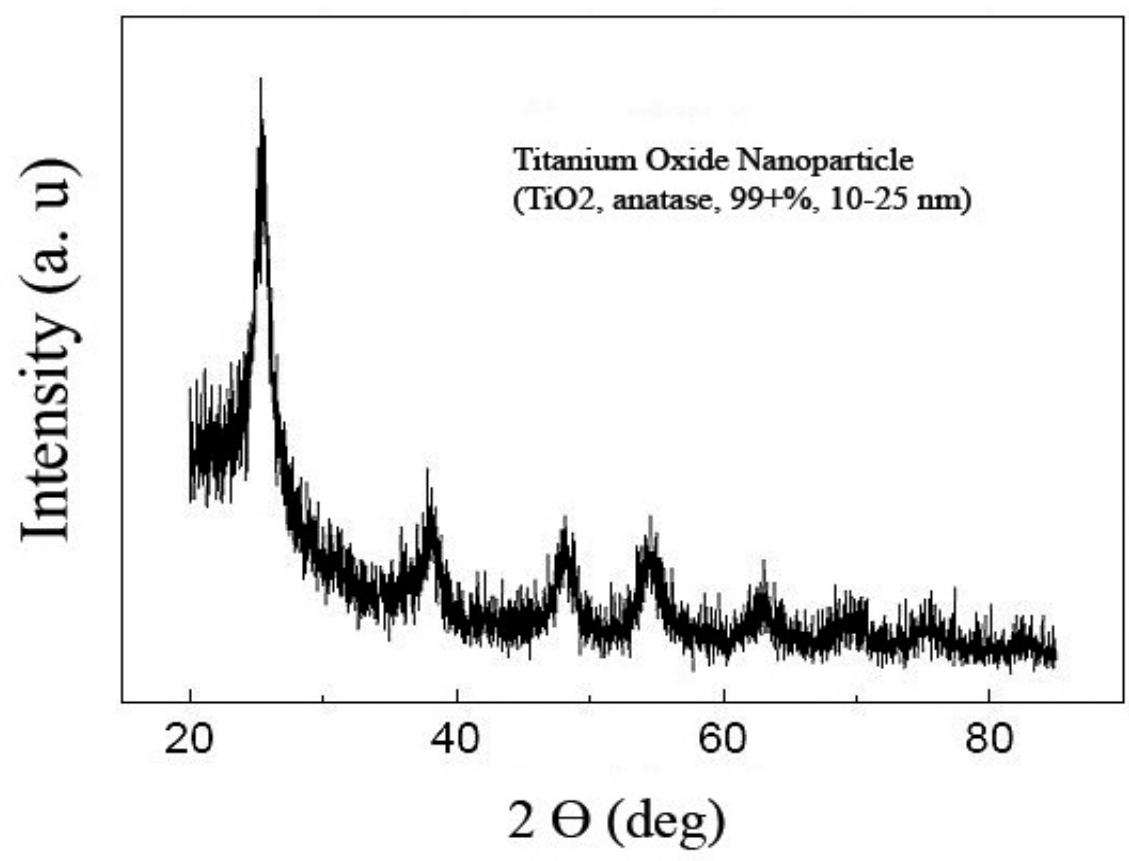

Figure 2. X-ray diffraction pattern $(\mathrm{XRD})$ of $\mathrm{TiO}_{2}$ nanoparticles. 


\section{Preparation of nanoparticle suspensions}

Stock suspensions of $\mathrm{TiO}_{2}$ NPs $(2000 \mathrm{mg} / \mathrm{L})$ were freshly prepared by dissolving the nanoparticles directly in deionized water and dispersed by ultrasonic vibration $(100 \mathrm{~W}, 40 \mathrm{kHz})$ for $30 \mathrm{~min}$. Titanium dioxide NP suspensions at the concentration of $0,500,1000$, and $2000 \mathrm{mg} / \mathrm{L}$ were prepared by dilution of the stock suspensions with deionized water. The suspensions were stirred for 1 min using small magnetic bars before use to avoid the aggregation of nanoparticles.

\section{Stress treatments}

Cadmium stress imposed by 50 and $100 \mathrm{mM} \mathrm{CdCl}_{2}$. Sodium nitroprusside was used as NO donor at concentrations of 0 and $100 \mu \mathrm{M}$ [36]. Then, seeds were subjected to the following basic treatment protocols as (a) $\left.\mathrm{TiO}_{2}, \mathrm{~b}\right) \mathrm{Cd}$ stress, c) $\mathrm{TiO}_{2}+\mathrm{Cd}$ stress and d) $\mathrm{TiO}_{2}+\mathrm{Cd}$ stress + SNP. The treatment with deionized water served as the control.

\section{Seed germination and seedling growth}

Seeds of similar size were randomly selected and immersed in a $5 \%$ sodium hypochlorite solution for $10 \mathrm{~min}$ and rinsed several times with distilled water to ensure surface sterility [34]. Sterilized seeds were evenly arrayed on $9 \mathrm{~cm}$ Petri dishes containing filter papers moistened with $9 \mathrm{~mL}$ of test solution. Petri dishes were sealed with tape to avoid evaporation and placed in a germinator under dark at $25 \pm 1{ }^{\circ} \mathrm{C}$ for seven days. Germination data were recorded at every $24 \mathrm{~h}$ interval following the International Rules for Seed Testing Association, ISTA [37]. Seeds were considered germinated when the radicle reached at least $2 \mathrm{~mm}$ in length [38]. At the end of the exposure, length and fresh weight of roots and shoots were measured using a ruler and digital balance respectively.

Germination percentages was calculated by the following equation [39]:

$$
(\mathrm{GP})=\left(\frac{\mathrm{N}_{i}}{\mathrm{~N}}\right) \times 100
$$

Where, $\mathrm{N}_{i}$ is the total number of germinated seeds at the end of experiment and $\mathrm{N}$ is the total number of seeds used in the test.

Germination energy was computed as describe by Amooaghaie et al. [40]:

$\mathrm{GE}=$ number of germinated seeds after three days/number of total seeds 
Germination rate was determined based on Maguire [41]:

Germination rate $(\mathrm{GR})=\left(\frac{\mathrm{a}}{1}\right)+\left(\mathrm{b}-\frac{\mathrm{a}}{2}\right)+\left(c-\frac{\mathrm{b}}{3}\right)+\ldots+\left(\mathrm{n}-\frac{\mathrm{n}-1}{\mathrm{~N}}\right)$

Where, a, b, c, and $\mathrm{n}$ are numbers of germinated seeds after 1, 2, 3, and $\mathrm{N}$ days from the start of imbibition. Mean Germination Time was recorded according to Ellis and Roberts [42]:

$$
(\mathrm{MGT})=\frac{1}{\mathrm{~T}} \sum \mathrm{N}_{i} \mathrm{D}_{i}
$$

Where, $\mathrm{N}_{i}$ is number of germinated seeds till $\mathrm{i}^{\text {th }} \mathrm{day}$, Di is number of days from start of experiment till $i^{\text {th }}$ counting, and T is total germinated seeds. MGT is a measure of the average length of time required for maximum germination of a seed lot.

Seedling vigor was computed based on Vashisth and Nagarajan [43]:

Vigor index $(\mathrm{VI})=$ germination $\% \times$ seedling length $($ root + shoot $)$

\section{Experimental design and statistical analysis}

A factorial experiment was arranged based on a completely randomized design (CRD). All germination tests were performed in triplicate and data were reported as the mean of three replicates. To compare treatments, least significant difference (LSD) tests were performed using the Statistical Analysis System (SAS, version 9.3). In all cases, $\mathrm{p}<0.05$ was considered significant.

\section{Results and Discussion}

Titanium dioxide and SNP suspensions either solely or in combination efficiently influenced seed germination under normal condition (Fig. 3). Germination percentage significantly was promoted up to $100 \%$ upon seed exposure to $1000 \mathrm{mg} / \mathrm{L} \mathrm{TiO}_{2}+\mathrm{SNP}(100 \mu \mathrm{M})$ treatment while germination reached $90 \%$ in the unexposed control treatment. A dose-dependent sharp decline was recorded in seeds treated by $\mathrm{CdCl}_{2}$ as a $\mathrm{Cd}$ stress agent, so germination percentages dropped to as low as $41 \%$ while the $\mathrm{Cd}$ concentration increased in the test medium (Fig. 3). Nevertheless, treatment by $\mathrm{TiO}_{2}$ and SNP solutions in mixture neutralized $\mathrm{Cd}$-induced adverse effects on seed germination. For instance, $1000 \mathrm{mg} / \mathrm{L} \mathrm{TiO} 2$ combined with 100 $\mu \mathrm{M}$ SNP promoted seed germination percentage up to $100 \%$ and $91 \%$ under $50 \mathrm{mM}$ and $100 \mathrm{mM} \mathrm{Cd}$, respectively (Fig. 3). Root and shoot length 
effectively influenced by $\mathrm{TiO}_{2}$ and SNP suspensions in the absence of $\mathrm{Cd}$ toxicity (Fig. 3). Cadmium stress immensely diminished root and shoot length in wheat seedlings, especially under higher $\mathrm{Cd}$ concentration. However, $\mathrm{TiO}_{2}+$ SNP treatments significantly ameliorated reductions in root and shoot length triggered by $\mathrm{Cd}$ stress. Similar to the response of root and shoot length to $\mathrm{TiO}_{2}+\mathrm{SNP}$ treatment, both root and shoot fresh weight responded positively to $\mathrm{TiO}_{2} \mathrm{NP}$ and SNP suspensions. As shown in Fig. 3, 500 and $1000 \mathrm{mg} / \mathrm{L} \mathrm{TiO}_{2}+\mathrm{SNP}(100 \mu \mathrm{M})$ treatments notably enhanced root and shoot fresh weight under normal conditions. Cadmium treatment dose-dependently decreased root and shoot fresh weight in wheat seedlings; however, declining trends in root and shoot fresh weight caused by $\mathrm{Cd}$ toxicity significantly reversed by protective role of $\mathrm{TiO}_{2}$ and SNP suspensions in alleviating negative effects of $\mathrm{Cd}$ on root and shoot fresh weight. Compared to untreated control seeds, mean germination time decreased in seeds exposed to $\mathrm{TiO}_{2}+\mathrm{SNP}$ treatments. In contrast, $500 \mathrm{mg} / \mathrm{L} \mathrm{TiO}_{2}$ combined with $100 \mu \mathrm{M}$ SNP significantly accelerated mean germination time in treated seeds under non-stress conditions. Exposure to different $\mathrm{Cd}$ concentrations postponed mean germination time in wheat seeds. Nevertheless, mean germination time in Cd-exposed seeds was positively accelerated by adding $\mathrm{TiO}_{2}$ and $\mathrm{SNP}$ suspensions in the test medium. Germination rate was also impressed by $\mathrm{TiO}_{2}$ and SNP solutions under both control and cadmium stress in the same way previously stated regarding mean germination time (Fig. 3). Regarding seed vigor index, a statically significant difference was observed followed by seed exposure to $\mathrm{TiO}_{2}$ and SNP suspensions either solely or in combined compared to untreated seeds. Cd stress induced by $\mathrm{CaCl}_{2}$ led to extremely reduced seed vigor which intensified as $\mathrm{Cd}$ concentrations increased in the test solution. However, seed vigor dramatically affected by $\mathrm{TiO}_{2}$ plus SNP treatments (Fig. 3). For example, vigor index in seeds treated by combined $\mathrm{TiO}_{2}(1000 \mathrm{mg} / \mathrm{L})+\mathrm{SNP}(100 \mu \mathrm{M})$ suspensions experienced up to two-fold increase under $50 \mathrm{mM} \mathrm{Cd}$ concentration. Likewise, seed vigor remarkably promoted up to nineteen-fold under $100 \mathrm{mM} \mathrm{Cd}$ stress when seeds were exposed to $\mathrm{TiO}_{2}(2000 \mathrm{mg} / \mathrm{L})+\mathrm{SNP}(100 \mu \mathrm{M})$ solutions in combination. Germination energy showed positive, null and even negative responses to different $\mathrm{TiO}_{2}+\mathrm{SNP}$ combinations under control condition. Cadmium chloride concentrations induced significant reductions in germination energy of wheat seeds. Unlike trends observed in normal condition, $\mathrm{TiO}_{2}+\mathrm{SNP}$ suspensions considerably relieved $\mathrm{Cd}$-stimulated decline in germination energy (Fig. 3). 
a)

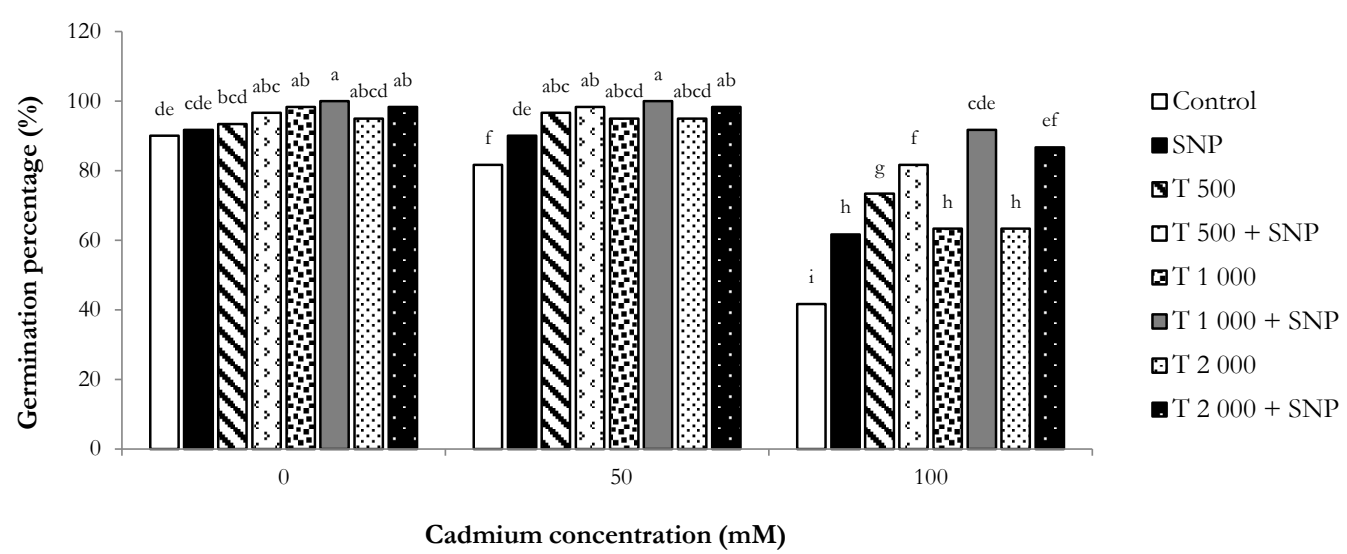

b)

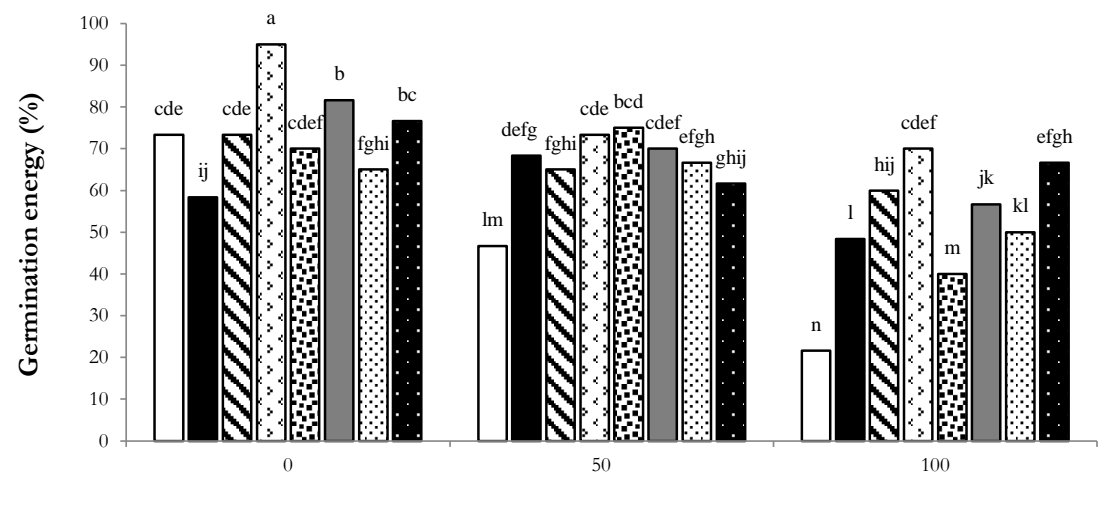

$\square$ Control

- SNP

$\mathbf{\Delta} 500$

๑T $500+$ SNP

由 T 1000

$\square \mathrm{T} 1000+\mathrm{SNP}$

छТ 2000

- $\mathrm{T} 2000+\mathrm{SNP}$

Cadmium concentration (mM)

c)

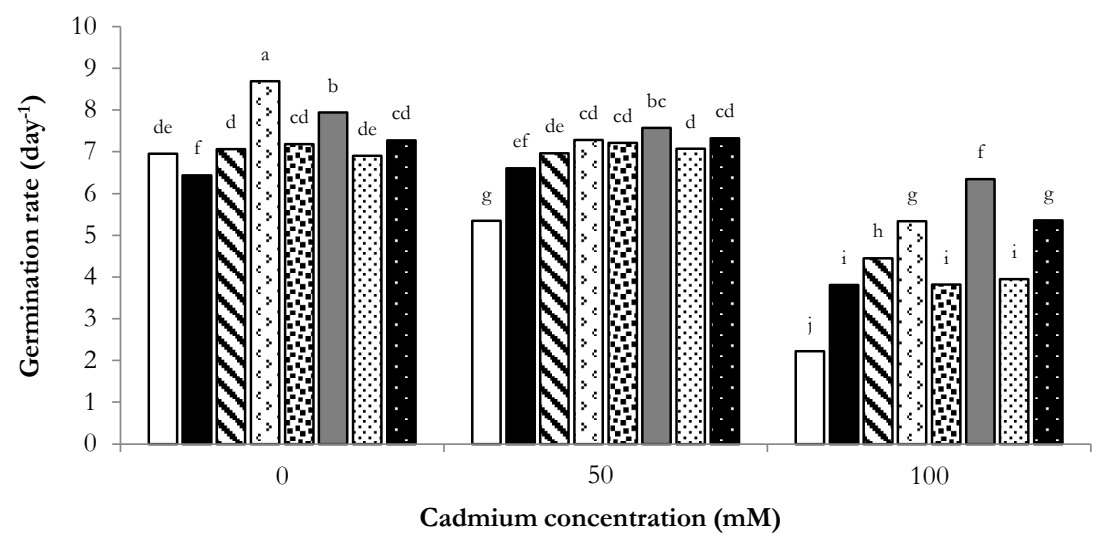

$\square$ Control

- SNP

ฮ $\mathrm{T} 500$

๑T $500+\mathrm{SNP}$

由 $\mathrm{T} 1000$

口T $1000+$ SNP ๒ 2000

-T $2000+$ SNP

d)

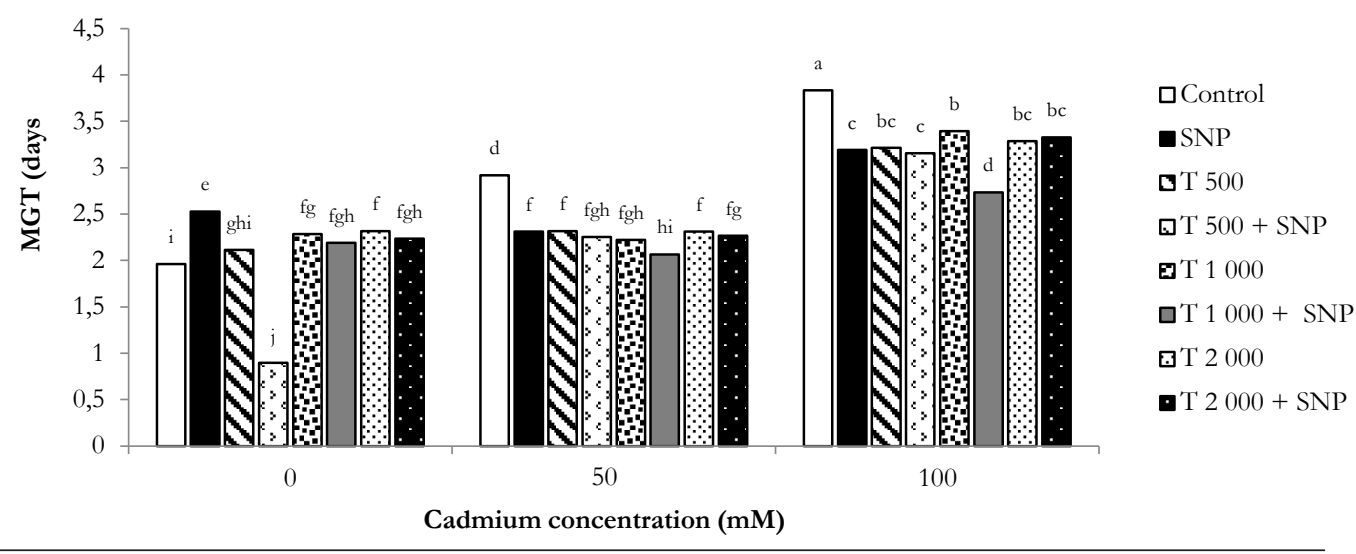


e)

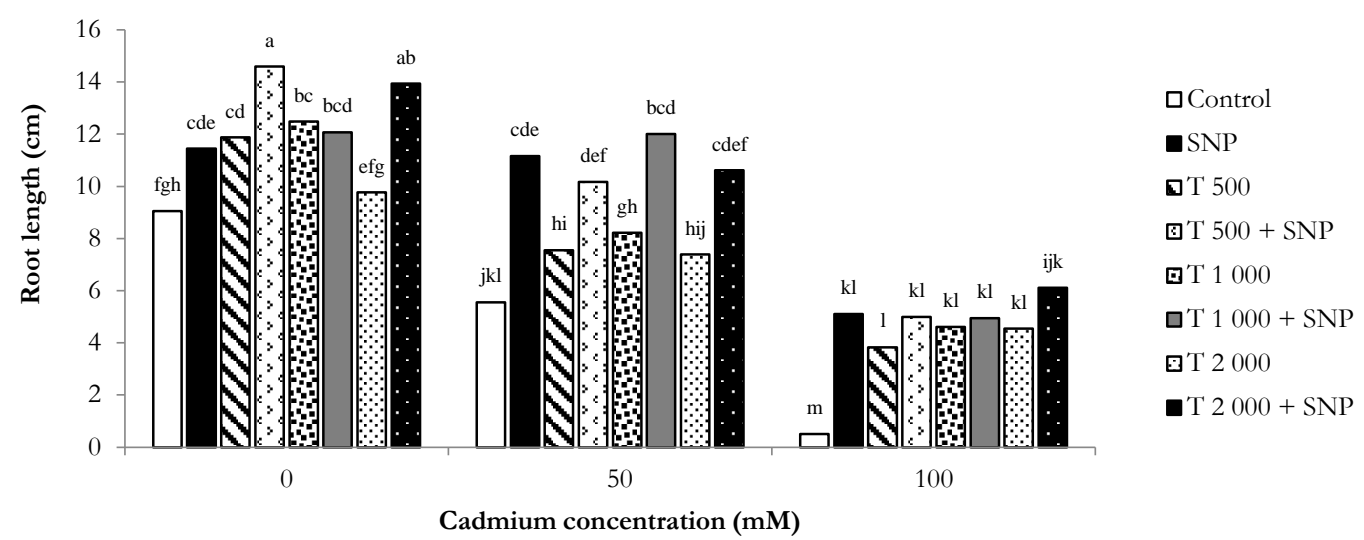

f)

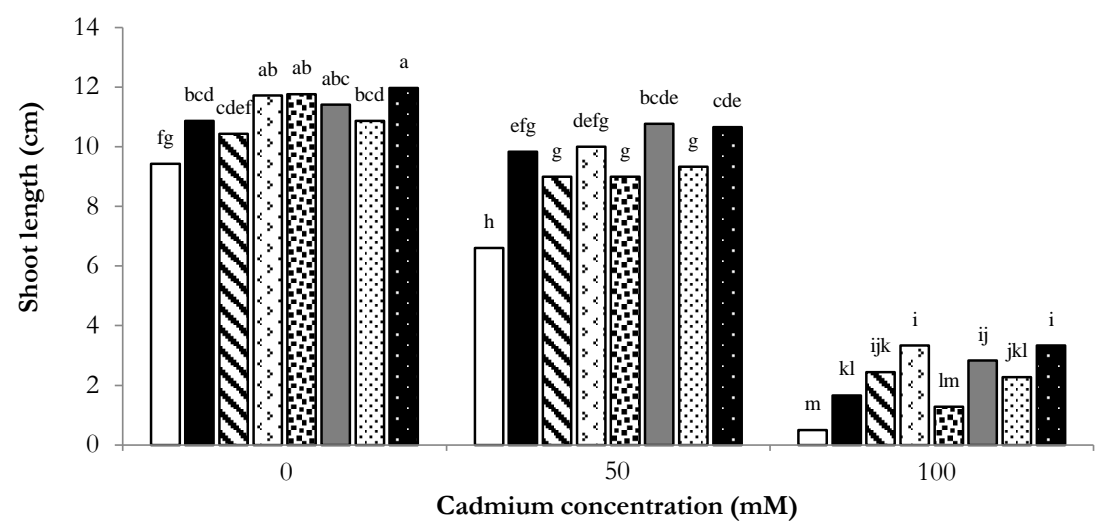

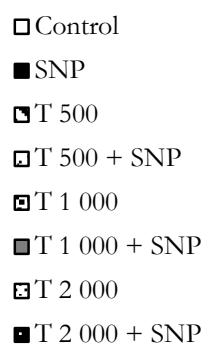

g)

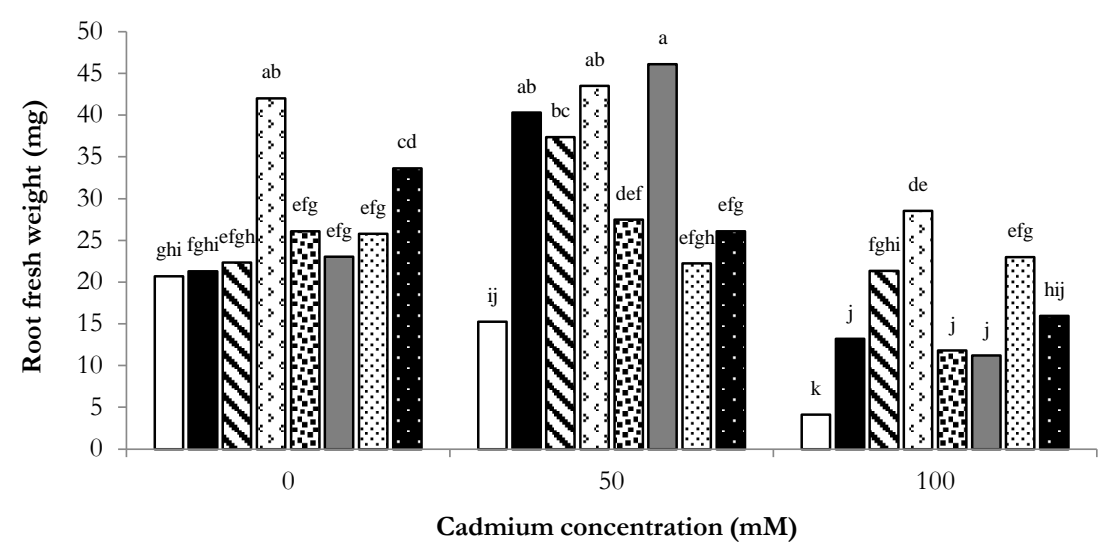

$\square$ Control

SNP

จ 500

๑ $500+$ SNP

뚜 1000

口T $1000+$ SNP

T 2000

- $\mathrm{T} 2000+\mathrm{SNP}$

h)

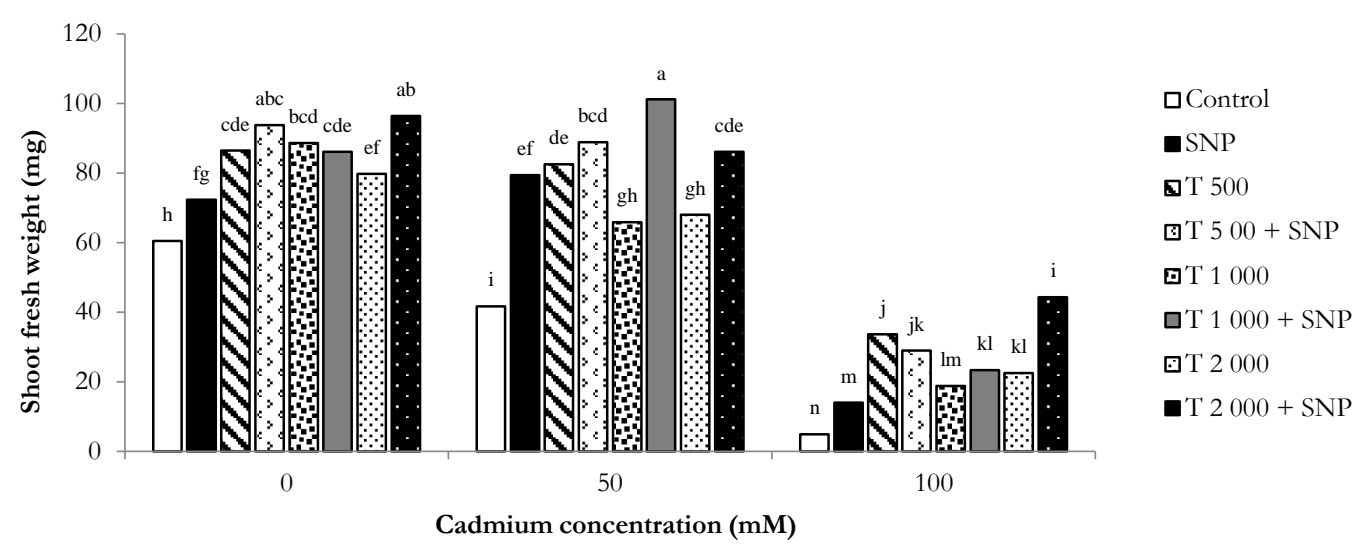


i)

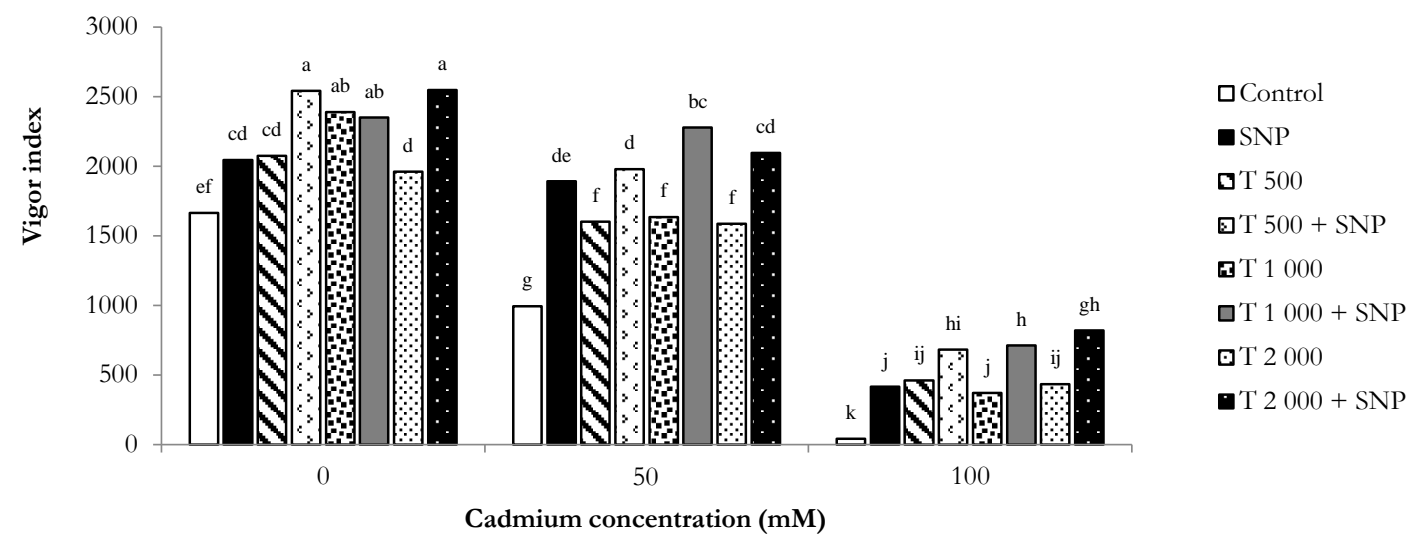

Figure 3. Impacts of $\mathrm{TiO}_{2} \mathrm{NPs}$ (T: 500,1000 and $2000 \mathrm{mg} / \mathrm{L}$ ) and SNP $(100 \mu \mathrm{M})$ suspensions on a) Germination percentage, b) Germination energy, c) Germination rate, d) Mean germination time (MGT), e) Root length, f) Shoot length, g) Root fresh weight, h) Shoot fresh weight and i) Vigor index of wheat under Cd stress. Data are the mean of three replicates. Different letters represent significant differences between the treatment means at $\mathrm{p}<0.05$.

Our results indicated that $\mathrm{Cd}$ stress considerably inhibited seed germination and early growth in wheat seedlings. Reduced germination indices such as germination percentage, root and shoot length, root and shoot fresh weight, and vigor in wheat seedlings under $\mathrm{Cd}$ stress conditions may be attributed to induced water shortage caused by $\mathrm{CdCl}_{2}$ suspensions. Many germination-related processes such as gene transcription and translation, respiration and energy metabolism, early reserve mobilization, and DNA repair could also occur during seed treatment [44] although often limited due to reduced water supply compared to normal germination [45, 46]. The root length reduction may be attributed to lower cellular division and elongation during germination [47]. The root/shoot ratio is an important 
index for measuring the development of seedling roots, and plants with higher root/shoot ratios are more capable of absorbing water and minerals [48]. Our results revealed that $\mathrm{Cd}$ stress stimulated by $\mathrm{CdCl}_{2}$ concentrations adversely affected all germination and growth parameters in germinating seeds. However, it was found that Cd stress, especially in $100 \mathrm{mM}$ concentrations, had more severe inhibitory impacts on wheat germination and growth. Previous experiments indicated that $\mathrm{Cd}$ coud inhibit germination and growth of wheat [49-51]. The decreased growth and germination may be associated with several disturbances in germination metabolism which is a highly complex multistage process. Roots are the first organs subjected to pollutants, and therefore toxic symptoms are more apparent in roots rather than shoots [52]. Reduced shoot length, biomass, protein content, and activities of antioxidant enzymes by $\mathrm{Cd}$ toxicity have been documented previously $[53,54]$.

Seed germination and root elongation are two standard criteria of phytotoxicity recommended by U.S. Environmental Protection Agency [34]. Improved root and shoot length accompanied by enhanced root and shoot fresh weight in wheat seedlings in the current study may be as a result of $\mathrm{TiO}_{2}$ NPs uptake via roots. Nanoparticles uptake across the cell wall is mostly dependent on the size of the particles, and the pores of the cell wall [55 - 57]. Due to the small diameter of $\mathrm{TiO}_{2} \mathrm{NPs}$, these nanoparticles might penetrate plant roots via pores in the cell wall. As demonstrated previously, smaller $\mathrm{NP}$ with a higher surface reactivity might enlarge root pores or create new ones, leading to higher hydromineral flow in roots [58]. Subsequently, this elevated nutrient uptake is responsible for the increased root length. Also, increased shoot and root length in the present study may be attributed to the early germination caused by $\mathrm{TiO}_{2} \mathrm{NPs}$ and SNP treatments. It was shown that rapid embryo growth occurred when the obstacle to germination was removed [59]. Uptake of $\mathrm{TiO}_{2}$ nanoparticles and increased root length has been recorded in wheat plants after exposure to $\mathrm{TiO}_{2} \mathrm{NPs}$ [60]. On the contrary, it was reported that $\mathrm{TiO}_{2}$ NPs had no impact [61] or even negative impact [62] on biomass in wheat.

In the presence of different $\mathrm{TiO}_{2}$ suspensions, most of the germination indices such as germination percentage, germination rate, germination energy, and vigor index promoted in wheat seeds under both normal and stress conditions. Improved seed germination indices in wheat upon exposure to $\mathrm{TiO}_{2}$ NPs have been previously reported by Mahmoodzadeh and Aghili [63], Jaberzadeh et al. [64] and Feizi et al. [2]. According to the obtained results, we postulated that $\mathrm{TiO}_{2}$ NPs ability to enhance seed germination and early growth of wheat under control and stress condition might have originated 
from its unique structural features (i.e., small particle size, large surface area, and photocatalytic properties). These structural features contribute to some key physiological processes in germinating seeds via facilitating water uptake [65], scavenging stress-induced ROS accumulation [66] and accelerating cellular growth and developments [67] in plants.It is well known that $\mathrm{TiO}_{2}$ NPs stimulate oxidation-reduction reactions via the superoxide ion radical during germination, leading to quenching free radicals in the germinating seeds. In turn, oxygen generated in such process could also be involved in respiration, which would further promote germination [68]. Water uptake in seed germination is critical because mature seeds are relatively dry and require a sufficient amount of water to initiate cellular metabolism and growth. Seed coat plays a unique role in protecting the embryo, and only nanoparticles that pass through the seed coat can affect seed germination and seedling growth [69]. Nanoparticles may create large new pores in the seed coat and therefore facilitate the process of water uptake inside the seed embryo, and accelerate germination rate [70]. Elevated nitrate reductase enzyme, improved seed function regarding absorbing and utilizing water and fertilizer and boosted seed antioxidant system was observed in soybean plants upon exposure to $\mathrm{TiO}_{2}$ and $\mathrm{SiO}_{2}$ nanoparticles [13]. Reduced oxidative stress by reducing $\mathrm{H}_{2} \mathrm{O}_{2}$, superoxide radicals, and malonyldialdehyde content, and increasing some enzymes such as superoxide dismutase, ascorbate peroxidase, guaiacol peroxidase, and catalase activities [71] by nanoparticles contributed to improved seed germination in some plant species. Ameliorative effects of $\mathrm{TiO}_{2}$ nanoparticles could also be due to antimicrobial and other properties of anatase crystalline structure of $\mathrm{TiO}_{2}$ that improve plant resistance to stress [72]. $\mathrm{TiO}_{2}$ NPs can also incite cell division and cell size in the root tip during germination process under dark conditions and consequently contribute to rapid emergence by increasing root length [59]. It seems that Titanium dioxide NPs may act as an alternative plant growth regulator and play a role similar to plant hormones such as cytokinin and gyberline $[73,74]$ as indicated by the ability to stimulate plant cell division and induce cellular development. Previous studies have also introduced $\mathrm{TiO}_{2}$-anatase nanoparticles as an effective photocatalyst which can enhance cell growth as well as plant fresh and dry weight by improving photosynthetic efficiency and nitrogen metabolism $[29,71,75]$.

As revealed by our experiment, supplemental SNP, as NO donor, might improve germination and subsequent seedling growth in wheat under either normal or stressed media. However, promoting impacts of SNP on germination indices were more evident when seeds were subjected to Cd stress triggered by $\mathrm{CdCl}_{2}$. The enhancement of wheat seed germination and seedling 
growth under $\mathrm{Cd}$ stress may be attributed to the promoting effect of $\mathrm{NO}$ in regulating endogenous auxins and gibberellins [76], increasing pectin and hemicelluloses content in the root cell wall [77], scavenging Cd-stimulated ROS [24], and modifications in gene expression [78]. Exogenous NO donor, SNP, dose-dependently alleviated the inhibition of rice seed germination indices and seedling growth caused by $\mathrm{Cd}$ stress via counteracting the adverse effects of $\mathrm{Cd}$ on germination index, vigor index, root and shoot length and fresh weight [27].

The positive role of SNP on germination percentage, germination rate, germination energy and vigor index either when applied solely or in combination with $\mathrm{TiO}_{2}$ suspensions shows that $\mathrm{NO}$ may be involved in energy metabolism in seeds during germination. Abiotic stresses have been demonstrated to restrict the mobilization of starchy endosperm reserves in several species, as a result of inhibition of different enzymatic activities $[79,80]$. Starch endosperm is the major part of wheat seeds, so its mobilization by amylase is required for wheat seed germination. It is known that NO is responsible for embryo extension and reserve degradation under normal and stress conditions and plays an important role in $\alpha$-amylase, $\beta$-amylase and protease mobilization in wheat seeds during early germination [81, 82]. Zheng et al. [83] suggested that exogenous nitric oxide improved seeds germination and seedling establishment in wheat under abiotic stress via an increase of amylase and starch metabolism. It seems that NO could participate in the regulation of the energy status of the seeds.

Our results showed that seed germination indices markedly improved upon seed exposure to $\mathrm{TiO}_{2}$ and SNP treatments, in particular, under stress conditions stimulated by $\mathrm{CdCl}_{2}$ concentrations. Moreover, it was previously proved that $\mathrm{Cd}$ stress adversely limits water uptake by seeds and consequently inhibits germination and seedling growth of wheat $[84,85,86]$. Cadmium can make plants highly vulnerable to another sort of environmental constraints, such as drought and salinity, due to the reduced water uptake ability of the minor root system $[87,88]$. Then the plant roots are not able to take up enough water for metabolism, so the plant suffers physiological drought under $\mathrm{Cd}$ stress. In addition to other improving functions of $\mathrm{TiO}_{2} \mathrm{NPs}$ and SNP during seed germination which was previously described, it seems that both $\mathrm{TiO}_{2}$ NPs and SNP are also involved in regulating mechanisms leading to the facilitating water uptake and improving tolerance to induced water deficit under $\mathrm{Cd}$ stress c ondition. Water deficit stimulates transcription of a large set of plant genes that results in the accumulation of new proteins such as water channel proteins (aquaporins) in plant tissues. Aquaporins which are present abundantly in the plasma and vacuolar membranes can 
facilitate and the regulate passive transit of water across membranes and trigger a ten- to twenty-fold increase in water permeability [89, 90]. On the other hand, aquaporins are proposed as pathways for nanoparticle uptake by plants [91, 92]. Recently, up-regulation of aquaporins upon exposure to nanoparticles has been reported [93]. Interestingly, it has been demonstrated that the $\mathrm{NO}$ signaling pathway is participated in regulating aquaporin genes expression in germinating seeds [94]. It was shown that induced seed germination upon exposure to SNP treatment is associated with the increased expression of several aquaporin genes, which possibly leads to an enhanced seed capacity for water uptake during imbibition and its subsequent development. Particular aquaporin isoforms can also enable the transit of small molecules such as $\mathrm{NO}, \mathrm{CO}$ or $\mathrm{H}_{2} \mathrm{O}_{2}$ [95].

\section{Conclusions}

Seed germination and early seedling growth of wheat positively affected by $\mathrm{TiO}_{2}$ and SNP treatments under normal and stress condition triggered $\mathrm{CdCl}_{2}$ suspensions. Also, it was also identified that the protective role of $\mathrm{TiO}_{2} \mathrm{NPs}$ and SNP on wheat seed germination indices markedly enhanced when $\mathrm{TiO}_{2}$ and SNP solutions were exerted in combination. However, promoting the impact of $\mathrm{TiO}_{2}$ and SNP treatments on wheat seed germination improved when seeds were exposed to Cd stress treatments compared to a non-stress condition. Overall, our results suggest that application of $\mathrm{TiO}_{2}$ nanoparticles and SNP may be a promising approach in ameliorating harmful effects of $\mathrm{Cd}$ stress on wheat seed germination and early growth.

\section{Acknowledgements}

We gratefully acknowledge the financial support provided by Bu-Ali Sina University. The authors also acknowledge Islamic Azad University, Kermanshah branch for providing some laboratory equipment.

\section{Conflict of interest}

The authors declare that they have no conflict of interest.

\section{References}

[1] Trujillo-Reyes J, Majumdar S, Botez C, Peralta-Videa J, GardeaTorresdey J. Exposure studies of core-shell $\mathrm{Fe} / \mathrm{Fe}_{3} \mathrm{O}_{4}$ and $\mathrm{Cu} / \mathrm{CuO}$ NPs to lettuce (Lactuca sativa) plants: are they a potential physiological and nutritional hazard?, Journal of Hazardous Materials, 267(28):255263, 2014.

doi: $10.1016 /$ j.jhazmat.2013.11.067 
[2] Feizi H, Rezvani Moghadam P, Shahtahmassebi N, Fotovat A. Impact of bulk and nanosized titanium dioxide $\left(\mathrm{TiO}_{2}\right)$ on wheat seed germination and seedling growth, Biological Trace Element Research, 146(1):101-106, 2012.

doi: 10.1007/s12011-011-9222-7

[3] Viana MM, Soares VF, Mohallem NDS. Synthesis and characterization of $\mathrm{TiO}_{2}$ nanoparticles, Ceramics International, 36(7):2047-2053, 2010.

doi: 10.1016/j.ceramint.2010.04.006

[4] Piccinno F, Gottschalk F, Seeger S, Nowack B. Industrial production quantities and uses of ten engineered nanomaterials for Europe and the world, Journal of Nanoparticles Research, 14:1109-1120, 2012.

doi: 10.1007/s11051-012-1109-9

[5] Servin AD, Morales MI, Castillo-Michel H, Hernandez-Viezcas JA, Munoz B, Zhao L, Nunez JE, Peralta-Videa JR, Gardea-Torresdey JL. Synchrotron verification of $\mathrm{TiO}_{2}$ accumulation in cucumber fruit: a possible pathway of $\mathrm{TiO}_{2}$ nanoparticle transfer from soil into the food chain, Environmental Science \& Technology, 47(20):11592-11598, 2013.

doi: $10.1021 /$ es403368j

[6] Menard A, Damjana D, Jeme C. Ecotoxicity of nanosized $\mathrm{TiO}_{2}$. Review of in vivo data, Environmental Pollution, 159(3):677-684, 2011.

doi: 10.1016/j.envpol.2010.11.027

[7] Shi H, Magaye R, Castranova V, Zhao J. Titanium dioxide NPs: a review of current toxicological data, Particle and Fibre Toxicology, 10:15-47, 2013.

doi: 10.1186/1743-8977-10-15

[8] Liu WK. $\mathrm{TiO}_{2}-\mathrm{NPs}$ application in agriculture: a review. In: Hendriks BP (ed) Agricultural Research Updates, vol 1, Nova Publisher, Hauppauge, New York, pp 137-145, 2011.

[9] Bhawana P, Fulekar MH. Nanotechnology: remediation technologies to clean up the environmental pollutants, Research Journal of Chemical Sciences, 2(2):90-96, 2012.

Retrieved from: http://www.isca.in/rjcs/Archives/v2/i2/15.php

[10] Zheng L, Hong FS, Lu SP, Liu C. Effect of nano-TiO 2 strength of naturally aged seeds and growth of spinach, Biological Trace Element Research, 104(1):82-93, 2005.

doi: 10.1385/BTER:104:1:083 
[11] Hong F, Zhou J, Liu C, Yang F, Wu C, Zheng L, Yang P. Effects of Nano- $\mathrm{TiO}_{2}$ on photochemical reaction of chloroplasts of spinach, Biological Trace Element Research, 105(1-3):269-279, 2005.

doi: 10.1385/BTER:105:1-3:269

[12] Yang F, Liu C, Gao F, Su M, Wu X, Zheng L, Hong F, Yang P. The improvement of spinach growth by nano-anatase $\mathrm{TiO}_{2}$ treatment is related to nitrogen photoreduction, Biological Trace Element Research, $119(1): 77-88,2007$.

doi: 10.1007/s12011-007-0046-4

[13] Lu CM, Zhang CY, Wen JQ, Wu GR, Tao MX. Research of the effect of nanometer on germination and growth enhancement of Glycine max and its mechanism, Soybean Science, 21(3):168-172, 2002.

[14] RoyChoudhury A, Roy C, Sengupta DN. Transgenic tobacco plants over expressing the heterologous lea gene Rab16 $\mathrm{A}$ from rice during high salt and water deficit display enhanced tolerance to salinity stress, Plant Cell Reports, 26(10):1839-1859, 2007.

doi: 10.1007/s00299-007-0371-2

[15] He JY, Ren YF, Wang FJ, Pan XB, Zhu C, Jiang DA. Characterization of cadmium uptake and translocation in a cadmium-sensitive mutant of rice (Oryza sativa L. ssp japonica), Archives of Environmental Contamination Toxicology, 57(2):299-306, 2009.

doi: $10.1007 / \mathrm{s} 00244-008-9273-8$

[16] Uraguchi S, Fujiwara T. Cadmium transport and tolerance in rice: perspectives for reducing grain cadmium accumulation, Rice, 5:5, 2012.

doi: 10.1186/1939-8433-5-5

[17] Siddiqui MH, Al-Whaibi MH, Basalah MO. Role of nitric oxide in tolerance of plants to abiotic stress, Protoplasma, 248(3):447-455, 2011.

doi: 10.1007/s00709-010-0206-9

[18] Baudouin E. The language of nitric oxide signaling, Plant Biology, 13(2):233-242, 2011.

doi: 10.1111/j.1438-8677.2010.00403.x

[19] Lin A, Wang Y, Tang J, Xue P, Li C, Liu L. Nitric oxide and protein S-nitrosylation are integral to hydrogen peroxide-induced leaf cell death in rice, Plant Physiology, 158:451-464, 2012.

doi: 10.1104/pp.111.184531 
[20] Corpas FJ, Leterrier M, Valderrama R, Airaki M, Chaki M, Palma JM, Barroso JB. Nitric oxide imbalance provokes a nitrosative response in plants under abiotic stress, Plant Science, 181:604-61, 2011.

doi: 10.1016/j.plantsci.2011.04.005

[21] Singh HP, Kaur S, Batish DR, Sharma VP, Sharma N, Kohli RK. Nitric oxide alleviates arsenic toxicity by reducing oxidative damage in the roots of Oryza sativa (rice). Nitric Oxide 20(4):289-297, 2009.

doi: 10.1016/j.niox.2009.02.004

[22] Xiong J, Fu G, Tao L, Zhu C. Roles of nitric oxide in alleviating heavy metal toxicity in plants, Archives of Biochemistry and Biophysics, 497(1-2):13-20, 2010.

doi: $10.1016 /$ j.abb.2010.02.014

[23] Hao GP, Zhang JH. The role of nitric oxide as a bioactive signaling molecule in plants under abiotic stress. In: Hayat S, Mori M, Pichtel J, Ahmad A (eds), Nitric oxide in plant physiology, Weinheim, Wiley-VCH Verlag, pp 115-138, 2010.

doi: 10.1002/9783527629138.ch9

[24] Singh HP, Batish DR, Kaur G, Arora K, Kohli RK. Nitric oxide (as sodium nitroprusside) supplementation ameliorates $\mathrm{Cd}$ toxicity in hydroponically grown wheat roots, Environmental and Experimental Botany, 63(1-3):158-167, 2008.

doi: 10.1016/j.envexpbot.2007.12.005

[25] Qiu ZB, Guo JL, Zhang MM, Lei MY, Li ZL. Nitric oxide acts as a signal molecule in microwave pretreatment induced cadmium tolerance in wheat seedlings, Acta Physiologiae Plantarum, 35(1):65-73, 2013.

doi: $10.1007 /$ s11738-012-1048-1

[26] Alemayehu A, Zelinová V, Bočová B, Huttová J, Mistrík I, Tamás L. Enhanced nitric oxide generation in root transition zone during the early stage of cadmium stress is required for maintaining root growth in barley, Plant and Soil, 390(1-2):213-222, 2015.

doi: $10.1007 /$ s11104-015-2397-5

[27] He J, Ren Y, Chen X, Chen H. Protective roles of nitric oxide on seed germination and seedling growth of rice (Oryza sativa L.) under cadmium stress, Ecotoxicology and Environmental Safety, 108:114-119, 2014.

doi: 10.1016/j.ecoenv.2014.05.021 
[28] Ma YH, Kuang LL, He X, Bai W, Ding YY, Zhang ZY, Zhao YL, Chai ZF. Effects of rare earth oxide nanoparticles on root elongation of plants, Chemosphere, 78(3):273-279, 2010.

doi: 10.1016/j.chemosphere.2009.10.050

[29] Yang F, Hong FS, You WJ, Liu C, Gao FQ, Wu C, Yang P. Influence of nano-anatase $\mathrm{TiO}_{2}$ on the nitrogen metabolism of growing spinach, Biological Trace Element Research, 110(2):179-190, 2006.

doi: 10.1385/BTER:110:2:179

[30] Khodakovskaya M, Dervishi E, Mahmood M, Xu Y, Li Z, Watanabe F, Biris AS. Carbon nanotubes are able to penetrate plant seed coat and dramatically affect seed germination and plant growth, ACS Nano, 3(10):3221-3227, 2009.

doi: $10.1021 / \mathrm{nn} 900887 \mathrm{~m}$

[31] Canas JE, Long MQ, Nations S, Vadan R, Dai L, Luo MX, Ambikapathi $\mathrm{R}$, Lee EH, Olszyk D. Effects of functionalized and nonfunctionalized single-walled carbon nanotubes on root elongation of select crop species, Environmental Toxicology and Chemistry, 27(9):1922-1931, 2008.

doi: $10.1897 / 08-117.1$

[32] Doshi R, Braida W, Christodoulatos C, Wazne M, O'Connor G. Nano-aluminum: transport through sand columns and environmental effects on plants and soil communities, Environmental Research, 106:296-303, 2008.

doi: 10.1016/j.envres.2007.04.006

[33] Song U, Shin M, Lee G, Roh J, Kim Y, Lee EJ. Functional analysis of $\mathrm{TiO}_{2}$ nanoparticle toxicity in three plant species, Biological Trace Element Research, 155(1):93-103, 2013.

doi: 10.1007/s12011-013-9765-x

[34] United States Environmental Protection Agency (USEPA). Ecological Effects Test Guidelines Terrestrial Plant Toxicity, Tier I (Seedling Emergence). 1996.

[35] Organization for Economic Cooperation and Development (OECD). OECD Guidelines for the testing of chemicals: proposals for updating guideline 208-Terrestrial Plant Test: Seedling Emergence and Seedling Growth Test. 2003.

[36] Hu KD, Hu LY, Li YH, Zhang FQ, Zhang H. Protective roles of nitric oxide on germination and antioxidant metabolism in wheat seeds under copper stress, Plant Growth Regulation, 53(3):173-183, 2007.

doi: 10.1007/s10725-007-9216-9 
[37] International Seed Testing Association (ISTA). International rules for seed testing, Seed Science Technology, 4:51-177, 1976.

[38] International Seed Testing Association (ISTA). ISTA Rules, International Seed Testing Association, Zurich, Switzerland, 2009.

[39] Bajji M, Kinet JM, Lutts S. Osmotic and ionic effects of $\mathrm{NaCl}$ on germination, early seedling growth, and ion content of Atriplex halimus (Chenopodiaceae), Canadian Journal of Botany, 80(3): 297-304, 2002.

doi: $10.1139 /$ b02-008

[40] Amooaghaie R, Tabatabaei F, Ahadi AM. Role of hematin and sodium nitroprusside in regulating Brassica nigra seed germination under nanosilver and nitrate silver stresses, Ecotoxicology and Environmental Safety, 113:259-270, 2015.

doi: 10.1016/j.ecoenv.2014.12.017

[41] Maguire JD. Speed of germination-aid in selection and evaluation for seedling emergence and vigor, Crop Science Society of America, 2:176-177, 1962.

doi: $10.2135 /$ cropsci1962.0011183X000200020033x

[42] Ellis RA, Roberts EH. The quantification of ageing and survival in orthodox seeds, Seed Sciences Technology, 9: 373-409, 1981.

[43] Vashisth A, Nagarajan S. Effect on germination and early growth characteristics in sunflower (Helianthus annuus) seeds exposed to static magnetic field, Journal of Plant Physiology, 167:149-156, 2010.

doi: 10.1016/j.jplph.2009.08.011

[44] Varier A, Vari AK, Dadlani M. The subcellular basis of seed priming, Current Science, 99:450-456, 2010.

[45] Chen F, Bradford KJ. Expression of an expansin is associated with endosperm weakening during tomato seed germination, Plant Physiology, 124:1265-1274, 2000.

[46] Li F, Wu X, Tsang E, Cutler AJ. Transcriptional profiling of imbibed Brassica napus seed, Genomics, 86:718-730, 2005.

doi: 10.1016/j.ygeno.2005.07.006

[47] Muscolo A, Sidari M, Anastasi U, Santonoceto C, Maggio A. Effect of PEG-induced drought stress on seed germination of four lentil genotypes, Journal of Plant Interactions, 9:354-363, 2014.

doi: 10.1080/17429145.2013.835880 
[48] Huang XH, Liu Y, Li JX, Xiong XZ, Chen YH, Yin XH, Feng DL. The response of mulberry trees after seedling hardening to summer drought in the hydro-fluctuation belt of Three Gorges Reservoir Areas, Environmental Science and Pollution Research, 20:7103-7111, 2013.

doi: 10.1007/s11356-012-1395-x

[49] Ci D, Jiang D, Dai T, Jing Q, Cao W. Variation in cadmium tolerance and accumulation and their relationship in wheat recombinant inbred lines at seedling stage, Biological Trace Element Research, 142:807-818, 2011.

doi: $10.1007 /$ s12011-010-8812-0

[50] Rizwan M, Meunier JD, Davidian JC, Pokrovsky OS, Bovet N, Keller C. Silicon alleviates Cd stress of wheat seedlings (Triticum turgidum L. cv. Claudio) grown in hydroponics, Environmental Science and Pollution Research, 23:1414-1427, 2016.

doi: $10.1007 /$ s11356-015-5351-4

[51] Arshad M, Ali S, Noman A, Ali Q, Rizwan M, Farid M, Irshad MK. Phosphorus amendment decreased cadmium (Cd) uptake and ameliorates chlorophyll contents, gas exchange attributes, antioxidants and mineral nutrients in wheat (Triticum aestivum L.) under Cd stress, Archives of Agronomy and Soil Science, 62:533-546, 2016.

doi: 10.1080/03650340.2015.1064903

[52] Arora S, Sharma P, Kumar S, Nayan R, Khanna PK, Zaidi MGH. Gold-nanoparticle induced enhancement in growth and seed yield of Brassica juncea, Plant Growth Regulation, 66:303-310, 2012.

doi: 10.1007/s10725-011-9649-z

[53] Verma K, Mehta SK, Shekhawat GS. Nitric oxide (NO) counteracts cadmium induced cytotoxic processes mediated by reactive oxygen species (ROS) in Brassica juncea: cross-talk between ROS, NO and antioxidant responses, BioMetals, 26:255-269, 2013.

doi: 10.1007/s10534-013-9608-4

[54] Sharma I, Pati PK, Bhardwaj R. Regulation of growth and antioxidant enzyme activities by 28-homobrassinolide in seedlings of Raphanus sativus L. under cadmium stress, Indian Journal of Biochemistry Biophysics, 47:172-177, 2010.

[55] Albersheim P. Plant Cell Walls: From Chemistry to Biology, New York, USA, Garland Science, 2011.

[56] Glenn JB, White SA, Klaine SJ. Interactions of gold nanoparticles with freshwater aquatic macrophytes are size and species dependent, Environmental Toxicology and Chemistry, 31:194-201, 2012.

doi: $10.1002 /$ etc. 728 
[57] Judy JD, Unrine JM, Rao W, Wirick S, Bertsch PM. Bioavailability of gold nanomaterials to plants: Importance of particle size and surface coating, Environmental Science \& Technology, 46:8467-74, 2012.

doi: $10.1021 /$ es3019397

[58] Asli S, Neumann PM. Colloidal suspensions of clay or titanium dioxide nanoparticles can inhibit leaf growth and transpiration via physical effects on root water transport, Plant, Cell \& Environment, 32:577-584, 2009.

doi: 10.1111/j.1365-3040.2009.01952.x

[59] Dehkourdi EH, Mosavi M. Effect of anatase nanoparticles $\left(\mathrm{TiO}_{2}\right)$ on parsley seed germination (Petroselinum crispum) in vitro, Biological Trace Element Research, 155:283-286, 2013.

doi: 10.1007/s12011-013-9788-3

[60] Larue C, Laurette J, Herlin-Boime N, Khodja H, Fayad B, Flank AM, Brisset F, Carriere M. Accumulation, translocation and impact of $\mathrm{TiO}_{2}$ nanoparticles in wheat (Triticum aestivum ssp.): influence of diameter and crystal phase, Science of the Total Environment, 431:197-208, 2012.

doi: 10.1016/j.scitotenv.2012.04.073

[61] Jacob DL, Barchardt JD, Navaratnam L, Otte ML, Bezbaruah A. Uptake and translocation of Ti from nanoparticles in crops and wetland plants, International Journal of Phytoremediation, 15:142-153, 2013.

doi: 10.1080/15226514.2012.683209

[62] Du W, Sun Y, Ji R, Zhu J, Wu J, Guo H. TiO 2 and $\mathrm{ZnO}$ nanoparticles negatively affect wheat growth and soil enzyme activities in agricultural soil, Journal of Environmental Monitoring, 13:822-828, 2011.

doi: $10.1039 / \mathrm{c} 0 \mathrm{em} 00611 \mathrm{~d}$

[63] Mahmoodzadeh H, Aghili R. Effect on Germination and Early Growth Characteristics in Wheat Plants (Triticum aestivum L.) Seeds Exposed to $\mathrm{TiO}_{2}$ Nanoparticles, Journal of Chemical Health Risks, 4:29-36, 2014.

[64] Jaberzadeh A, Moaveni P, Moghadam HRT, Zahedi H. Influence of bulk and nanoparticles titanium foliar application on some agronomic traits, seed gluten and starch contents of wheat subjected to water deficit stress, Notulae Botanicae Horti Agrobotanici Cluj-Napoca, 41:201-207, 2013.

[65] Qi M, Liu Y, Li T. Nano-TiO 2 improve the photosynthesis of tomato leaves under mild heat stress, Biological Trace Element Research, 156:323-328, 2013.

doi: 10.1007/s12011-013-9833-2 
[66] Mohammadi R, Maali-Amiri R, Abbasi A. Effect of $\mathrm{TiO}_{2}$ nanoparticles on chickpea response to cold stress, Biological Trace Element Research, 152:403-410, 2013.

doi: $10.1007 /$ s12011-013-9631-x

[67] Mandeh M, Omidi M, Rahaie M. In vitro influences of $\mathrm{TiO}_{2}$ nanoparticles on barley (Hordeum vulgare L.) tissue culture, Biological Trace Element Research, 150:376-380, 2012.

doi: $10.1007 / \mathrm{s} 12011-012-9480-z$

[68] Khot LR, Sankaran S, Maja JM, Ehsani R, Schuster EW. Applications of nanomaterials in agricultural production and crop protection: a review, Crop Protection, 35:64-70, 2012.

doi: 10.1016/j.cropro.2012.01.007

[69] Lin D, Xing B. Phytotoxicity of nanoparticles: Inhibition of seed germination and root growth, Environmental Pollution, 150:243-250, 2007.

doi: 10.1016/j.envpol.2007.01.016

[70] Navarro E, Baun A, Behra R, Hartmann NB, Filser J, Miao A, Quigg A, Santschi PH, Sigg L. Environmental behavior and ecotoxicity of engineered nanoparticles to algae, plants, and fungi, Ecotoxicology, 17:372-386, 2008.

doi: 10.1007/s10646-008-0214-0

[71] Zheng L, Mingyu S, Xiao W, Chao L, Chunxiang Q, Liang C, Hao H, Xiao-qing L, Fashui H. Antioxidant stress is promoted by nano-anatase in spinach chloroplasts under UV-B radiation, Biological Trace Element Research, 121:69-79, 2008.

doi: 10.1007/s12011-007-8028-0

[72] Clément L, Hurel C, Marmier N. Toxicity of $\mathrm{TiO}_{2}$ nanoparticles to cladocerans, algae, rotifers and plants-effects of size and crystalline structure, Chemosphere, 90:1083-1090, 2013.

doi: 10.1016/j.chemosphere.2012.09.013

[73] Davies PJ. The plant hormones: their nature, occurrence, and functions. In: Davies PJ (ed) Plant hormones: biosynthesis, signal transduction and action, 3rd edn, Springer, Dordrecht, 2010.

[74] Sauret-Güeto S, Calder G, Harberd NP. Transient gibberellin application promotes Arabidopsis thaliana hypocotyl cell elongation without maintaining transverse orientation of microtubules on the outer tangential wall of epidermal cells, The Plant Journal, 69:628-639, 2012.

doi: 10.1111/j.1365-313X.2011.04817.x 
[75] Mingyu S, Liu J, Yin S, Linglan M, Hong F. Effects of nano-anatase on the photosynthetic improvement of chloroplast damaged by linolenic acid, Biological Trace Element Research, 124:173-183, 2008.

doi: 10.1007/s12011-008-8134-7

[76] Xu J, Wang W, Yin H, Liu X, Sun H, Mi Q. Exogenous nitric oxide improves antioxidative capacity and reduces auxin degradation in roots of Medicago truncatula seedlings under cadmium stress, Plant and Soil, 326:321-330, 2010.

doi: 10.1007/s11104-009-0011-4

[77] Xiong J, An L, Lu H, Zhu C. Exogenous nitric oxide enhances cadmium tolerance of rice by increasing pectin and hemicelluloses contents in root cell wall, Planta, 230:755-765, 2009.

doi: 10.1007/s00425-009-0984-5

[78] Wilson ID, Neill SJ, Hancock JT. Nitric oxide synthesis and signaling in plants, Plant Cell \& Environment, 31:622-631, 2008.

doi: 10.1111/j.1365-3040.2007.01761.x

[79] Dkhil BB, Denden M. Salt stress induced changes in germination, sugars, starch and enzyme of carbohydrate metabolism in Abelmoschus esculentus (L.) moench seeds, African Journal of Agricultural Research, 5:408-415, 2010 .

[80] Białecka B, Kępczyński J. Germination, $\alpha$-, $\beta$-amylase and total dehydrogenase activities of Amaranthus caudatus seeds under water stress in the presence of ethephon or gibberellin A3, Acta Biol Cracov Ser Bot, 52:7-12, 2010.

doi: 10.2478/v10182-010-0001-0

[81] Wu M, Wang F, Zhang C, Xie Y, Han B, Huang J, Shen W. Heme oxygenase-1 is involved in nitric oxide- and cGMP-induced $\alpha$-Amy2/54 gene expression in GA-treated wheat aleurone layers, Plant Molecular Biology, 81:27-40, 2013.

doi: $10.1007 /$ s11103-012-9979-x

[82] Zhang H, Shen WB, Zhang W, Xu LL. A rapid response of $\beta$-amylase to nitric oxide but not gibberellins in wheat seeds during the early stage of germination, Planta, 220:708-716, 2005.

doi: 10.1007/s00425-004-1390-7

[83] Zheng C, Jiang D, Liu F, Dai T, Liu W, Jing Q, Cao W. Exogenous nitric oxide improves seed germination in wheat against mitochondrial oxidative damage induced by high salinity, Environmental and Experimental Botany, 67:222-227, 2009.

doi: 10.1016/j.envexpbot.2009.05.002 
[84] Ji Y, Zhou Y, Ma C, Feng Y, Hao Y, Rui Y, Wu W, Gui X, Le VN, Han Y, Wang Y, Xing B, Liu L, Cao W. Jointed toxicity of $\mathrm{TiO}_{2} \mathrm{NPs}$ and $\mathrm{Cd}$ to rice seedlings: NPs alleviated $\mathrm{Cd}$ toxicity and $\mathrm{Cd}$ promoted NPs uptake, Plant Physiology and Biochemistry, 110:82-93, 2017.

doi: 10.1016/j.plaphy.2016.05.010

[85] Jiang F, Shen Y, Ma C, Zhang X, Cao W, Rui Y. Effects of $\mathrm{TiO}_{2}$ nanoparticles on wheat (Triticum aestivum L.) seedlings cultivated under super-elevated and normal CO2 conditions, PLOS ONE, 12:e0178088, 2017.

doi: 10.1371/journal.pone.0178088

[86] Konate A, He X, Zhang Z, Ma Y, Zhang P, Alugongo GM, Rui Y. Magnetic $\left(\mathrm{Fe}_{3} \mathrm{O}_{4}\right)$ nanoparticles reduce heavy metals uptake and mitigate their toxicity in wheat seedling, Sustainability, 9:790, 2017.

doi: $10.3390 /$ su9050790

[87] Ryser P, Emerson P. Growth, root and leaf structure, and biomass allocation in Leucanthemum vulgare Lam. (Asteraceae) as influenced by heavy-metal-containing slag, Plant and Soil, 301:315-324, 2007.

doi: $10.1007 /$ s11104-007-9451-x

[88] Santala KR, Ryser P. Influence of heavy-metal contamination on plant response to water availability in white birch, Betula papyrifera, Environmental and Experimental Botany, 66:334-340, 2009.

doi: 10.1016/j.envexpbot.2009.03.018

[89] Fitzpatrick KL, Reid RJ. The involvement of aquaglyceroporins in transport of boron in barley roots, Plant Cell \& Environment, 32:1357-1365, 2009.

doi: 10.1111/j.1365-3040.2009.02003.x

[90] Zangi R, Filella M. Transport routes of metalloids into and out of the cell: a review of the current knowledge, Chemico-Biological Interactions, 197:47-57, 2012.

doi: 10.1016/j.cbi.2012.02.001

[91] Kurepa J, Paunesku T, Vogt S, Arora H, Rabatic BM, Lu JJ, Wanzer MB, Woloschak GE, Smalle JA. Uptake and distribution of ultrasmall anatase $\mathrm{TiO}_{2}$ alizarin red $\mathrm{S}$ nanoconjugates in Arabidopsis thaliana, Nano Letters, 10:2296-2302, 2010.

doi: $10.1021 / \mathrm{nl} 903518 \mathrm{f}$

[92] Rico CM, Majumdar S, Duarte-Gardea M, Peralta-Videa JR, GardeaTorresdey JL. Interaction of nanoparticles with edible plants and their possible implications in the food chain, Journal of Agricultural and Food Chemistry, 59:3485-3498, 2011.

doi: $10.1021 /$ jf104517j 
[93] Khodakovskaya MV, de Silva K, Biris AS, Dervishi E, Villagarcia H. Carbon nanotubes induce growth enhancement of tobacco cells, ACS Nano, 6:2128-35, 2012.

doi: $10.1021 / \mathrm{nn} 204643 \mathrm{~g}$

[94] Liu HY, Yu X, Cui DY, Sun MH, Sun WN, Tang ZC, Kwak SS, $\mathrm{Su}$ WA. The role of water channel proteins and nitric oxide signaling in rice seed germination, Cell Research, 17:638-649, 2007.

doi: $10.1038 /$ cr.2007.34

[95] Wu B, Beitz E. Aquaporins with selectivity for unconventional permeants, Cellular and Molecular Life Sciences, 64:2413-2421, 2007.

doi: 10.1007/s00018-007-7163-2

Nanopartículas de dióxido de titanio y nitroprusiato de sodio alivian los efectos adversos del estrés por cadmio en la germinación y el crecimiento de as plántulas de trigo (Triticum aestivum L.)

Resumen. Se investigó el efecto de nanopartículas de dióxido de titanio $\left(\mathrm{TiO}_{2} \mathrm{NPs}\right)(0,500,1000$ and $2000 \mathrm{mg} / \mathrm{L})$ y nitroprusiato de sodio (SNP) (0 and $100 \mu \mathrm{M})$ como donador de óxido nítrico (NO), en la germinación de las semillas y el crecimiento de las plántulas de trigo bajo estrés por Cadmio (Cd) $\left(0,50\right.$ and $\left.100 \mathrm{mM} \mathrm{CdCl}_{2}\right)$. Se observaron tendencias decrecientes en los índices de germinación de las semillas de trigo expuestas a suspensiones de $\mathrm{CdCl}_{2}$. Estas tendencias fueron dependientes de la concentración, y más obvias ante alto estrés por Cd. El Nitroprusiato de Sodio exógeno (SNP) y las nanopartículas de $\mathrm{TiO}_{2}(\mathrm{NPs})$ afectaron positivamente la mayoría de los índices de germinación bajo condiciones normales y de estrés. En la mayoría de los casos, la aplicación combinada de suspensiones de $\mathrm{TiO}_{2} \mathrm{NPs}$ y SNP incrementó la función estimulante de ambos componentes y moderó los efectos adversos de los tratamientos de $\mathrm{Cd}$ en la geminación de las semillas de trigo y el crecimiento de las plántulas. Con el tratamiento de $2000 \mathrm{mg} / \mathrm{L}$ $\mathrm{TiO}_{2}+\mathrm{SNP}(100 \mu \mathrm{M})$ se registraron los mejores resultados en cuanto a los índices de germinación sometidos a bajo y alto estrés por Cd (50 and $100 \mathrm{mM} \mathrm{CdCl}_{2}$ ). En general, podría concluirse que la aplicación de $\mathrm{TiO}_{2}$ NPs en combinación con SNP podría ser una aproximación promisoria para contrarrestar los efectos adversos del estrés por $\mathrm{Cd}$ en la germinación de las semillas de trigo y en su crecimiento temprano.

Palabras clave: bestrés por Cadmio; germinación; óxido nítrico nanopartículas de $\mathrm{TiO}_{2}$; trigo 


\section{Nanopartículas de dióxido de titânio e nitroprussiato de sódio aliviam os efeitos adversos do estresse por cádmio na germinaçáo e no crescimento do trigo (Triticum aestivum L.)}

Resumo. Foram investigados os efeitos de nanopartículas de dióxido de titânio ( $\left.\mathrm{TiO}_{2} \mathrm{NPs}\right)(0,500,1000$ e $2000 \mathrm{mg} / \mathrm{L})$ e nitroprussiato de sódio (SNP) (0 e $100 \mu \mathrm{M})$ como donadoras de óxido nítrico (NO) na germinação de sementes e no crescimento de plântulas de trigo sob estresse por cádmio $(\mathrm{Cd})\left(0,50\right.$ e $\left.100 \mathrm{mM} \mathrm{CdCl}_{2}\right)$. Se observaram tendências decrescentes nos índices de germinação de sementes de trigo expostas a suspensões de $\mathrm{CdCl}_{2}$. Essas tendências foram dependentes da concentração, sendo mais evidentes frente ao alto estresse por $\mathrm{Cd}$. O nitroprussiato de sódio (SNP) e as nanopartículas de $\mathrm{TiO}_{2}$ (NPs) afetaram positivamente a maioria dos índices de germinação sob condições normais e de estresse. $\mathrm{Na}$ maioria dos casos, a aplicação combinada de suspensões de $\mathrm{TiO}_{2}$ NPs e SNP aumentou a função estimulante de ambos componentes e moderou os efeitos adversos dos tratamentos de $\mathrm{Cd}$ na germinação de semestres de trigo e no crescimento das plântulas. Com o tratamento de $2000 \mathrm{mg} / \mathrm{L} \mathrm{TiO}_{2}+\mathrm{SNP}(100 \mathrm{mM})$ se registraram os melhores resultados em quanto aos índices de germinação submetidos a baixo e alto estresse por Cd (50 e $100 \mathrm{mM} \mathrm{Cd})$. De modo geral, se pode concluir que a aplicação de $\mathrm{TiO}_{2}$ NPs em combinação com SNP poderia ser uma aproximação promissora para combater os efeitos adversos do estresse por $\mathrm{Cd}$ na germinação de sementes de trigo e no seu crescimento inicial.

Palavras-chave: Estresse por Cádmio; germinação; óxido nítrico; nanopartículas de $\mathrm{TiO}_{2}$; trigo 


\section{Javad Faraji}

Is a $\mathrm{PhD}$ (crop physiology) student in the Department of Agronomy and Plant Breeding, Faculty of Agriculture, Bu-Ali Sina University, Hamedan, Iran.

\section{Ali Sepehri}

Is an Associate Professor in the Department of Agronomy and Plant Breeding, Faculty of Agriculture, Bu-Ali Sina University, Hamedan, Iran. $\mathrm{He}$ is a member of Iranian Crop and Plant Breeding Association and Iranian Society of Seeds. He has more than 20 years of teaching and research experience with Undergraduate and Post Graduate students. His area of research is physiology of environmental stresses in plants and has published many articles in this field. 